\title{
Differences in size and reproductive output of loggerhead turtles Caretta caretta nesting in the eastern Mediterranean Sea are linked to foraging site
}

\author{
Samir H. Patel ${ }^{1, *}$, Aliki Panagopoulou ${ }^{1,2}$, Stephen J. Morreale ${ }^{3}$, Susan S. Kilham ${ }^{1}$, \\ Ioannis Karakassis ${ }^{4}$, Thomas Riggall ${ }^{2}$, Dimitris Margaritoulis ${ }^{2}$, James R. Spotila ${ }^{1}$ \\ ${ }^{1}$ Department of Biodiversity, Earth and Environmental Science, Drexel University, Philadelphia, PA 19104, USA \\ ${ }^{2}$ ARCHELON, The Sea Turtle Society of Greece, Athens, Greece \\ ${ }^{3}$ Department of Natural Resources, Cornell University, Ithaca, NY 14850, USA \\ ${ }^{4}$ University of Crete, Biology Department, Heraklion, Crete, Greece
}

\begin{abstract}
Foraging success affects reproductive output in sea turtles, and is therefore an important factor to measure in order to understand population dynamics. During 2010 and 2011, we used satellite telemetry to track the at-sea behavior of 20 post-nesting loggerhead turtles Caretta caretta from Rethymno, Crete, Greece. Nineteen transmitters provided location and dive data throughout the turtles' migration towards their foraging grounds and the transition into foraging behavior. We identified 3 foraging regions: (1) 9 turtles migrated southwest towards the North African coast, with 8 concentrated in the region of the Gulf of Gabès, Tunisia; (2) 6 turtles migrated north towards the Aegean Sea; and (3) 4 turtles did not take long-distance migrations, instead remaining resident within the waters of Crete. Two fitness proxies were associated with differences in post-nesting strategies. Turtles foraging in northern waters had significantly larger curved and straight carapace lengths and clutch sizes than turtles foraging near Crete or Africa. Those differences reflect the disparity in benthic prey abundances among the 3 regions. The Aegean had a higher abundance of macrobenthic fauna than the other 2 regions, and the Gulf of Gabès had an increased level of eutrophication. Deterioration of the aquatic resources in the Gulf of Gabès region may be a contributing factor in the observed steady decline in clutch size and total nests per season in 2 critical nesting beaches for loggerheads in Greece.
\end{abstract}

KEY WORDS: Gulf of Gabès · Aegean Sea $\cdot$ Crete $\cdot$ Overfishing $\cdot$ Eutrophication

\section{INTRODUCTION}

Each species requires access to resources to fulfill its ecological role. These resource requirements range from food availability, to adequate climate, predator avoidance, and success of offspring development. Seasonal fluctuations in resource availability may be the driving force for long-distance migrations displayed by many species, including whales, birds, and sea turtles (Corkeron \& Connor 1999, Boyle \& Conway 2007, Morreale et al. 2007). Sea tur- tles are the only reptiles to exhibit long-distance migrations over thousands of kilometers (Plotkin 2003). Starting as hatchlings, they emerge from nests and instinctually swim directly to the open ocean (Lohmann et al. 1997). After residing in large oceanic gyres, juvenile sea turtles move to common foraging grounds of their adult counterparts (Musick \& Limpus 1997). As adults, sea turtles migrate throughout the remainder of their lives to and from areas of breeding and foraging (Limpus et al. 1992), exhibiting a high level of foraging and nesting site fidelity 
over multiple years (Broderick et al. 2007, Casale et al. 2013).

Availability of resources can also affect more than the requirement to migrate. Resource availability can constrain energy budgets that will in turn influence body size (Wikelski \& Thom 2000) and reproductive output (Limpus \& Nicholls 1988, Solow et al. 2002), thereby affecting the population dynamics of the species (Jenouvrier et al. 2005, Wallace et al. 2006). Marine iguanas Amblyrhynchus cristatus, for example, shrank by as much as $20 \%$ within 2 yr due to low food abundance (Wikelski \& Thom 2000), while Adélie penguins Pygoscelis adeliae that demonstrated higher foraging efficiency also exhibited higher breeding success (Lescroël et al. 2010). Sea turtle reproductive output is influenced by foraging success (Wallace et al. 2006, Saba et al. 2007, 2008a,b, Bailey et al. 2012). In this context, a successful forager is one that expends minimal energy foraging with optimal gain, thus allowing for more energy to be expended on life history characteristics resulting in the highest reproductive output. For example, higher foraging success in leatherback turtles Dermochelys coriacea leads to larger clutch sizes and shorter remigration intervals (Wallace et al. 2006, Saba et al. 2007, 2008b, Bailey et al. 2012).

In the Mediterranean Sea, loggerhead turtles Caretta caretta are typically smaller than their Atlantic counterparts, and Tiwari \& Bjorndal (2000) suggested that this is due to the limited availability of high-quality nutrients in the region. Additionally, within the Mediterranean loggerhead population, there is a carapace size and clutch size dichotomy based on foraging area, with turtles feeding in northern waters being larger and producing larger clutch sizes than their southern counterparts (Zbinden et al. 2011, Schofield et al. 2013, Cardona et al. 2014). Loggerheads forage on a wide variety of benthic animals, especially on slow-moving invertebrates (Godley et al. 1997, Casale et al. 2008, Lazar et al. 2011). Throughout the eastern Mediterranean Sea, loggerheads forage primarily on mollusks, crustaceans, and echinoderms (Godley et al. 1997, Casale et al. 2008, Lazar et al. 2011). We combined these foraging data with the abundance of benthic prey from common foraging sites to determine a mechanism driving the dichotomy in fitness between loggerheads that migrate to different feeding areas.

Although previous studies in the Mediterranean have identified fitness differences between nesting populations of loggerheads, limited research into the drivers of these differences has been undertaken. Schofield et al. (2013) identified (from 65 tracked turtles, males and females, breeding near Zakynthos, Greece) that loggerheads foraging in higher latitudes in the eastern Mediterranean had a generally larger curved carapace length than those foraging in southern latitudes. Schofield et al. (2013) speculated that this relationship was due to the higher prey species richness found in northern foraging grounds. A similar telemetry study incorporating both body size and clutch size, conducted on the rookery of Zakynthos (Zbinden et al. 2011), found that loggerheads foraging in northern waters (Adriatic Sea) were on average $2.9 \mathrm{~cm}$ longer and produced clutches of 11.6 more eggs than those that migrated south to Tunisia. However, that study did not describe a mechanism responsible for that dichotomy. Cardona et al. (2014) sampled from 8 rookeries in the eastern Mediterranean Basin and found that adult females nesting primarily in western Greece and foraging in the Adriatic Sea or northern Ionian Sea had higher clutch sizes than those foraging within the Cretan continental shelf, the Levantine Basin, or the southwestern Ionian Sea adjacent to the Gulf of Gabès region. Cardona et al. (2014) suggested that this was related to higher primary productivity in the Adriatic and northern Ionian Seas compared with the other foraging sites. However, primary productivity does not necessarily translate into higher secondary productivity of benthic macroinvertebrates (see below). Similar trends have been reported for other loggerhead populations globally. For example, in Japan, adult female loggerheads foraging in the nutrient-poor oceanic environments are not only smaller, but also have 2.4 times less cumulative reproductive output than benthic foragers (Hatase et al. 2013).

We hypothesized that the trend in fitness differences for turtles in the eastern Mediterranean reflects the different prey resources of each foraging ground. Our data also suggest that since adult loggerheads throughout the eastern Mediterranean use the benthic environment for foraging, the differences in fitness parameters of subpopulations residing in different foraging grounds are a proxy for nutrient value and abundance of benthic species from those regions.

In order to identify post-nesting behaviors and key migratory pathways and foraging sites for turtles nesting in Rethymno, Crete, Greece, we deployed 20 satellite transmitters on post-nesting loggerheads. We also used 2 proxies of fitness, viz. carapace size and clutch size, to compare differences in groups exhibiting different post-nesting strategies (Wallace et al. 2006, Zbinden et al. 2011). 


\section{MATERIALS AND METHODS}

We carried out the study in collaboration with ARCHELON, the Sea Turtle Protection Society of Greece, during the sea turtle nesting seasons of 2010 and 2011. Between June and July of each year, we patrolled nightly, looking for nesting females, a total of $2 \mathrm{~km}$ on the 2 easternmost sectors of the nesting site at Rethymno, Crete, Greece $\left(35.385^{\circ} \mathrm{N}\right.$, $24.590^{\circ} \mathrm{E}$ ). These sections of beach have historically been patrolled by ARCHELON and have the highest density of nesting activity. Once a turtle was encountered, we waited for completion of egg laying and then measured carapace size. We then determined each turtle's current reproductive status with a portable real time ultrasound (2010: Aloka SSD500, 2011: Sonosite 180 Plus) using comparable methods described by Rostal et al. (1996) and Blanco et al. (2012b). We scanned 1 ovary and oviduct at a time by placing the ultrasound probe in the inguinal region above the hind flipper (Blanco et al. 2012b). The absence of maturing follicles in the ovary suggested that the female had just deposited her final nest for the season and would soon depart for her foraging grounds, making her suitable for our study.

\section{Satellite transmitters}

We used a tethering method, which provided a rapid processing time, extremely low hindrance and restraint to the turtle, low impact to the carapace, and extremely low level of drag compared to any direct attachment methods to the carapace (Logan \& Morreale 1994, Jones et al. 2011).

We followed a procedure developed by Morreale et al. (1996), Morreale (1999) and modified by Blanco et al. (2012a) to deploy the satellite transmitter to a sea turtle using a tether. First, we cleaned 1 of the 2 supracaudal scutes with $70 \%$ alcohol solution and then made a small circular incision $5 \mathrm{~mm}$ in diameter. The incision was cleaned using a topical antiseptic solution before inserting sterilized surgical tubing so as to prevent friction from the tether that would abrade the carapace. We used $400 \mathrm{lb}$ test monofilament fishing line for the tether, passed it through the rubber tubing, and secured it with 2 buttons made of strong high-density plastic on the dorsal and ventral side of the carapace. The purpose of these buttons was to inhibit contact between the tether and the carapace. Additionally, the button spread the force of the transmitter pulling on the carapace, thus reduc- ing its pressure and further limiting the impact of the attachment. The tether was adjusted to a length between 15 and $25 \mathrm{~cm}$ so as to ensure that it would not be entangled in the front flippers, which could interfere with the turtle's swimming and/or buoyancy in the water. All connection points were corrodible so that they would break away soon after the transmitter's battery life was depleted. The entire attachment process for 1 transmitter took less than $15 \mathrm{~min}$.

We obtained location and dive data for post-nesting female loggerheads using pop-up archival satellite transmitters with opportunistic transmissions. We used Wildlife Computers tag models Mk10-PAT for 19 turtles and Mk10-AF (with Fastloc GPS capabilities) for 1 individual. The transmitters weighed $\sim 115 \mathrm{~g}$ and had a buoyancy of $\sim 36 \mathrm{~g}$.

\section{Fitness proxies}

We measured curved carapace length (CCL) from the nuchal notch to the tip of the supracaudal scute and measured curved carapace width (CCW) from the widest points of the carapace. To take the straight carapace length (SCL) and width (SCW) measurements, we used calipers and measured from the same locations as done for the curved measurements. Measurements were made to the nearest $0.5 \mathrm{~cm}$. We also checked for scars and lesions on the carapace and flippers.

To determine clutch size, we used excavation data obtained from all known nests deposited by the turtles we tracked. Excavations were conducted $10 \mathrm{~d}$ after first hatching occurred and were performed following a protocol set forth by ARCHELON (Margaritoulis 2005). Nest contents were sorted into categories of hatched eggs, unhatched eggs, and hatchlings. Total clutch size was calculated as the sum of the hatched and unhatched eggs.

Turtle 11 was not included in carapace length or clutch size comparisons due to a lack of comparable data. This turtle had healed injuries to posterior marginal scutes, making length measurements impossible, and its monitored nest was partially lost to the sea prior to being excavated.

\section{Statistical analyses}

We compared clutch sizes and carapace sizes of turtles foraging in each region using an analysis of covariance (ANCOVA) and a 1-way ANOVA. The 
Table 1. Summary data of the 20 satellite tracked loggerhead turtles Caretta caretta from Rethymno, Crete. CCL (SCL): curved (straight) carapace length; CCW (SCW): curved (straight) carapace width; na: turtles did not achieve the criteria for those categories

\begin{tabular}{|c|c|c|c|c|c|c|c|c|c|c|}
\hline $\begin{array}{l}\text { Turtle } \\
\text { ID }\end{array}$ & $\begin{array}{l}\text { Site of } \\
\text { residency }\end{array}$ & $\begin{array}{c}\text { Post-nesting } \\
\text { date } \\
\text { (dd-mm-уууy) }\end{array}$ & $\begin{array}{l}\text { Transmission } \\
\text { duration } \\
\text { (d) }\end{array}$ & $\begin{array}{l}\text { Migration } \\
\text { duration } \\
\text { (d) }\end{array}$ & $\begin{array}{c}\text { Track } \\
\text { length } \\
(\mathrm{km})\end{array}$ & $\begin{array}{l}\text { CCL } \\
(\mathrm{cm})\end{array}$ & $\begin{array}{l}\text { SCL } \\
(\mathrm{cm})\end{array}$ & $\begin{array}{c}\text { CCW } \\
(\mathrm{cm})\end{array}$ & $\begin{array}{l}\text { SCW } \\
(\mathrm{cm})\end{array}$ & $\begin{array}{l}\text { Mean clutch } \\
\text { size } \\
\text { (no. of eggs) }\end{array}$ \\
\hline 1 & Gulf of Gabès & $26-07-2011$ & 64.0 & 31.0 & 1152 & 84.5 & 81.0 & 72.0 & 58.0 & 132 \\
\hline 2 & Gulf of Gabès & $16-07-2011$ & 27.0 & 27.0 & 1121 & 87.0 & 82.5 & 74.0 & 53.0 & 95 \\
\hline 3 & Gulf of Gabès & $28-07-2010$ & 109.7 & 57.0 & 1614 & 80.0 & 78.0 & 76.0 & 56.0 & 104 \\
\hline 4 & Gulf of Gabès & $28-07-2010$ & 61.1 & 33.0 & 1350 & 81.0 & 75.5 & 72.5 & 57.0 & 67 \\
\hline 5 & Gulf of Gabès & $26-07-2010$ & 164.9 & 33.0 & 1416 & 82.0 & 78.0 & 73.0 & 58.0 & 79 \\
\hline 6 & Gulf of Gabès & $24-07-2011$ & 251.6 & 30.0 & 1522 & 81.0 & 78.0 & 75.0 & 59.0 & 99 \\
\hline 7 & Gulf of Gabès & $11-08-2011$ & 126.3 & 31.0 & 1303 & 82.0 & 78.0 & 72.5 & 57.5 & 111 \\
\hline 8 & Gulf of Gabès & $10-07-2011$ & 163.1 & 62.0 & 2347 & 81.0 & 77.5 & 71.0 & 57.0 & 80 \\
\hline 9 & NE Libya & $28-07-2011$ & 133.1 & 17.0 & 764 & 82.5 & 78.5 & 74.0 & 56.0 & 132 \\
\hline 10 & Aegean Sea & 24-07-2011 & 119.1 & 11.0 & 465 & 78.5 & 73.0 & 71.0 & 57.5 & 131 \\
\hline 11 & Aegean Sea & $18-07-2011$ & 23.0 & 15.0 & 777 & na & na & 69.0 & 55.0 & na \\
\hline 12 & Aegean Sea & $11-07-2011$ & 162.2 & 7.0 & 315 & 91.0 & 87.0 & 75.0 & 61.0 & 120 \\
\hline 13 & Aegean Sea & $13-08-2011$ & 230.2 & 9.0 & 339 & 90.0 & 87.0 & 77.0 & 61.0 & 134 \\
\hline 14 & Aegean Sea & $20-07-2011$ & 192.4 & 5.0 & 237 & 84.5 & 79.5 & 70.5 & 59.0 & 118 \\
\hline 15 & Aegean Sea & $11-07-2011$ & 71.2 & 10.0 & 441 & 86.0 & 84.5 & 77.0 & 58.5 & 145 \\
\hline 16 & Crete & $29-07-2010$ & 171.7 & na & 240 & 82.0 & 78.0 & 73.0 & 58.0 & 77 \\
\hline 17 & Crete & 08-07-2011 & 201.3 & na & 112 & 78.0 & 74.0 & 71.0 & 54.0 & 150 \\
\hline 18 & Crete & $11-07-2011$ & 250.3 & na & 65 & 75.0 & 71.0 & 66.0 & 51.5 & 91 \\
\hline 19 & Crete & 25-07-2011 & 180.0 & na & 72 & 75.5 & 71.0 & 69.0 & 56.5 & 92 \\
\hline 20 & na & $26-07-2010$ & 11.8 & na & na & 84.0 & 81.0 & 72.0 & 56.0 & 76 \\
\hline \multirow{2}{*}{$\begin{array}{c}\text { African } \\
\text { coast }\end{array}$} & Mean & 25 July & 122.3 & 35.7 & 1398.8 & 82.3 & 78.6 & 73.3 & 56.8 & 99.9 \\
\hline & $\mathrm{SD}$ & $8.8 \mathrm{~d}$ & 67.7 & 14.4 & 435.0 & 2.2 & 2.0 & 1.6 & 1.7 & 19.1 \\
\hline \multirow{2}{*}{$\begin{array}{l}\text { Aegean } \\
\text { Sea }\end{array}$} & Mean & 21 July & 133.0 & 9.5 & 429.0 & 86.0 & 82.2 & 73.3 & 58.7 & 127.0 \\
\hline & $\mathrm{SD}$ & $12.2 \mathrm{~d}$ & 77.4 & 3.4 & 190.0 & 5.0 & 6.0 & 3.5 & 2.3 & 12.3 \\
\hline \multirow[t]{2}{*}{ Crete } & Mean & 18 July & 200.8 & na & 122.3 & 77.6 & 73.5 & 69.8 & 55.0 & 99.2 \\
\hline & $\mathrm{SD}$ & $10.3 \mathrm{~d}$ & 35.3 & na & 81.2 & 3.2 & 3.3 & 3.0 & 2.9 & 25.8 \\
\hline \multirow{2}{*}{$\begin{array}{l}\text { All } \\
\text { turtles }\end{array}$} & Mean & 23 July & 135.7 & 25.2 & 823.8 & 82.4 & 78.6 & 72.5 & 57.0 & 107.2 \\
\hline & SD & $9.9 \mathrm{~d}^{1}$ & 74.1 & 17.3 & 649.5 & 4.3 & 4.6 & 2.8 & 2.4 & 22.1 \\
\hline
\end{tabular}

ANCOVA was used to determine whether clutch size was significantly related to body size, while the ANOVA was used to identify significant differences in fitness metrics between regions. For all analyses, we used a significance level of $\alpha=0.05$. We performed all statistical analyses in $\mathrm{R}$ ( $\mathrm{R}$ Core Team 2015).

\section{Benthic assessments}

We compiled benthic assessments of the Aegean Sea, the sea around Crete and the Gulf of Gabès region from Karakassis \& Eleftheriou (1997), El Lakhrach et al. (2012), and Dimitriou et al. (2012). El Lakhrach et al. (2012) sampled the Gulf of Gabès region from 36 stations between depths of 20 and $260 \mathrm{~m}$. Twenty-one stations were $<60 \mathrm{~m}$ and 15 stations were $>60 \mathrm{~m}$ (El Lakhrach et al. 2012). For sampling in the $<60 \mathrm{~m}$ stations, a 'shrimp' type trawl with a horizontal opening of $23 \mathrm{~m}$ was used and in the
$>60 \mathrm{~m}$ stations a vertical opening trawl with a horizontal opening of $15 \mathrm{~m}$ was used; both trawls had a mesh diameter of $20 \mathrm{~mm}$ (El Lakhrach et al. 2012).

The benthic environment around Crete was sampled from 148 stations, ranging in depth from 40 to $200 \mathrm{~m}$ (Dimitriou et al. 2012). Sixty-seven stations were $<40 \mathrm{~m}_{;} 42$ stations were between 40 and $100 \mathrm{~m}$, and 39 stations were between 100 and $200 \mathrm{~m}$ (Dimitriou et al. 2012). In the Aegean Sea and within Cretan waters, samples were taken from 21 stations at $<50 \mathrm{~m}$ (Dimitriou et al. 2012). At each station, the benthic environment was sampled using a $0.1 \mathrm{~m}^{2}$ top-opening Smith-McIntyre grab (Karakassis \& Eleftheriou 1997). Samples were then sieved over a $0.5 \mathrm{~mm}$ mesh (Karakassis \& Eleftheriou 1997).

From the results of these benthic assessments, we calculated abundances (ind. ha ${ }^{-1}$ ) of mollusks, crustaceans, and echinoderms. We selected prey species based on loggerhead diet studies in the Mediterranean Sea conducted by Godley et al. (1997), Casale et al. (2008), and Lazar et al. (2011). 


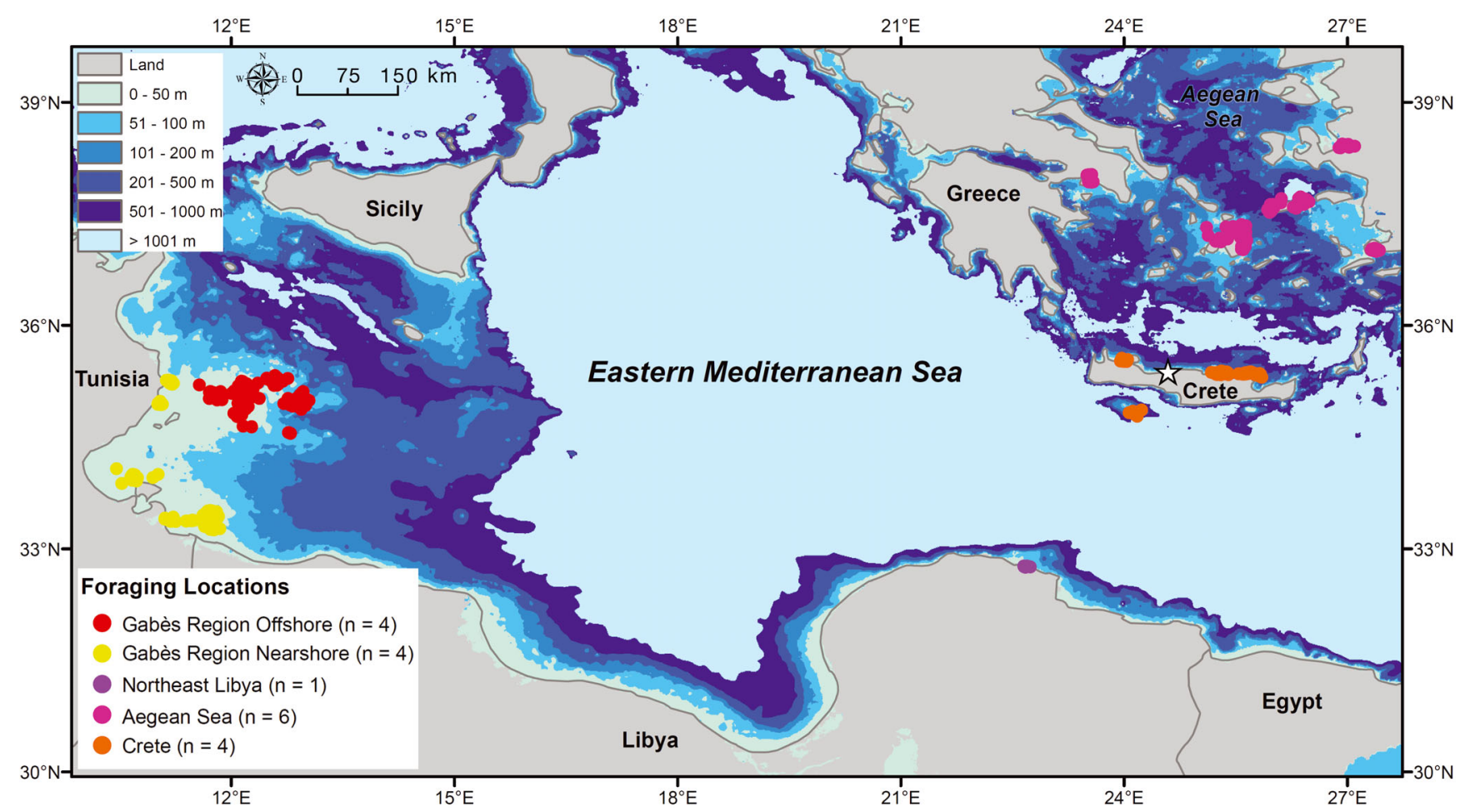

Fig. 1. Foraging locations for loggerhead turtles Caretta caretta tracked from Crete. White star represents Rethymno, Crete, the site from where the transmitters were deployed

\section{RESULTS}

We received location, dive and temperature data from 19 of the 20 transmitters through the postnesting migrations of the turtles (Table 1). The 20th transmitter stopped functioning within 2 wk of deployment. These turtles exhibited 3 different post-nesting migrations (Fig. 1). Nine individuals (Turtles 1-9) traveled southwest towards the North African coast, with 8 of them eventually settling in the Gulf of Gabès region of Tunisia and the ninth maintaining residency along the northeast coast of Libya. Six turtles (Turtles 10-15) traveled north into the Aegean Sea, and 4 turtles (Turtles 16-19) remained within the waters of the Cretan continental shelf.

The overall average $( \pm \mathrm{SD}) \mathrm{CCL}$ for the 18 turtles whose fitness proxies could be measured was $82.3 \pm$ $4.4 \mathrm{~cm}$, ranging from 75.0 to $91.0 \mathrm{~cm}$, and the average SCL was $78.4 \pm 4.7 \mathrm{~cm}$ with a range of 71.0 to $87.0 \mathrm{~cm}$. One-way ANOVA revealed significant differences between CCLs $(F=6.9, \mathrm{p}=0.007, \mathrm{df}=17)$ and SCLs $(F=$ $6.0, p=0.01, d f=17$ ) for turtles from each foraging region (Fig. 2). Turtles that migrated to the Aegean Sea $(\mathrm{n}=5)$ were the longest, those that migrated to the African coast $(n=9)$ were the second longest, and turtles that remained resident in Crete $(n=4)$ were the shortest. There was also a significant difference in
SCW between the turtles that migrated to the different areas $(F=3.5, \mathrm{p}=0.05, \mathrm{df}=18)$, but no difference in $\operatorname{CCW}(F=2.7, \mathrm{p}=0.09, \mathrm{df}=18)$. The average SCW was $57.0 \pm 2.4 \mathrm{~cm}$ with a range of 51.5 to $61.0 \mathrm{~cm}$. The overall average CCW for the 19 turtles was $72.5 \pm$ $2.9 \mathrm{~cm}$, ranging from 66.0 to $77.0 \mathrm{~cm}$. Turtles that migrated to the Aegean Sea $(\mathrm{n}=6)$ had the widest $\mathrm{SCW}$, those that migrated to the African coast $(\mathrm{n}=9)$ had the second widest, and turtles that remained resident in Crete $(n=4)$ had the narrowest SCW.

We also found significant differences between clutch sizes from nests laid by turtles exhibiting each migratory strategy $(F=6.4, \mathrm{p}=0.005, \mathrm{df}=32)$. The largest clutch sizes occurred for turtles that traveled to the Aegean Sea $(n=9)$, while those that stayed near Crete $(n=6)$ or traveled to the African coast $(n=$ 18) had much smaller clutch sizes. The overall mean clutch size for all known nests of these monitored turtles $(n=33)$ was $107 \pm 22.1$ eggs (mean $\pm S D)$ with a range of 67 to 150 eggs.

The ANCOVA indicated that clutch sizes were not significantly related to body size (SCL: $\mathrm{p}=0.2, \mathrm{df}=$ 31; CCL: $\mathrm{p}=0.2, \mathrm{df}=31$; SCW: $\mathrm{p}=0.6, \mathrm{df}=31$; CCW: $\mathrm{p}=0.5, \mathrm{df}=31$ ). As a result, body size was a not a good predictor of clutch size.

In the Gulf of Gabès region, El Lakhrach et al. (2012) found a total of 131 species of echinoderms, 

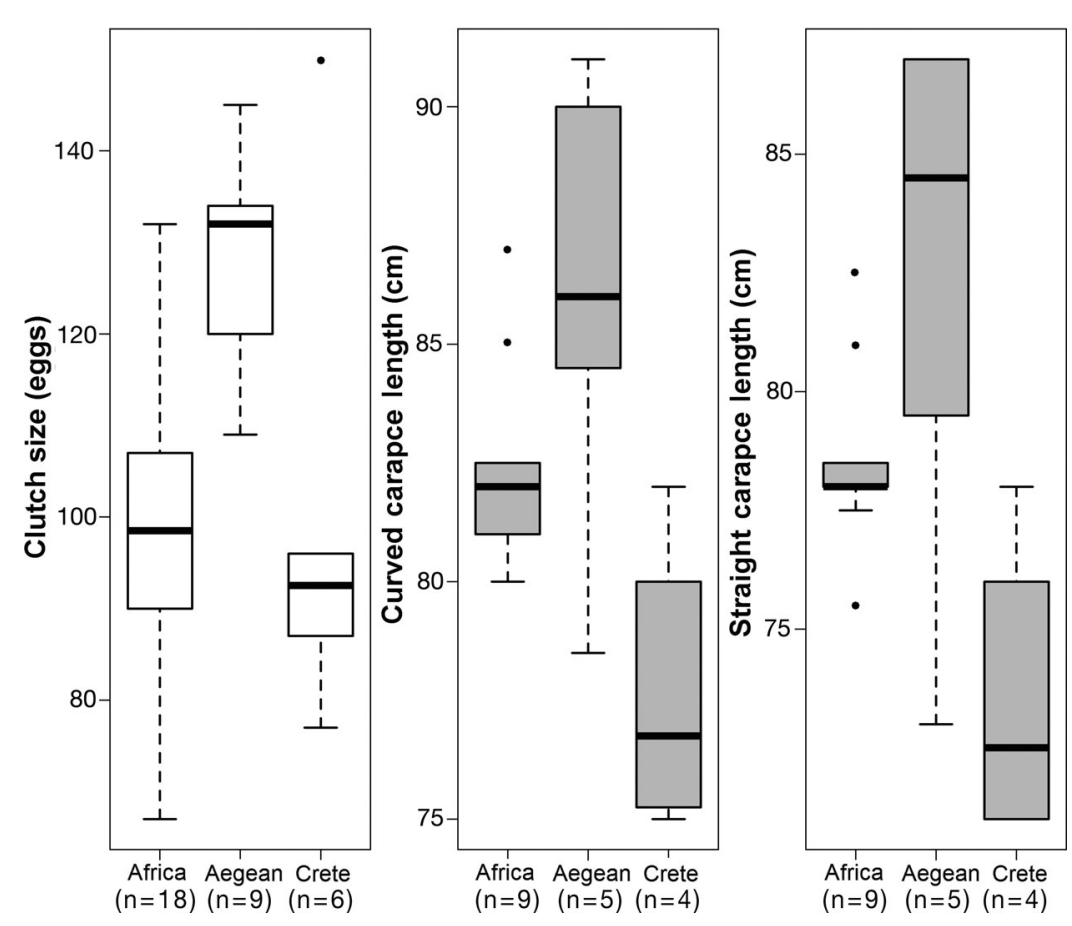

Fig. 2. Relationship between fitness proxies (clutch size and carapace length) and foraging sites of loggerhead turtles Caretta caretta for the 3 migratory strategies. Horizontal bars $=$ median; box $=50 \%$; whiskers $=$ range of observations within 1.5 times the interquartile range from the edges of the box; circle $=$ observations farther than 1.5 times the interquartile range gerhead turtle nesting beaches in Greece, some nesting populations continue to decline (Margaritoulis et al. 2009, 2011). One population of particular conservation concern is the third largest nesting population in Greece, located at Rethymno, Crete. This population is an important component of gene flow between western Greek and more eastern Mediterranean nesting populations (Carreras et al. 2007). Despite the importance of Rethymno, very limited research has been done there. Beyond the efforts centered on beach protection and flipper tagging, only 1 satellite transmitter was previously deployed on a single nesting turtle (Margaritoulis \& Rees 2011). Our data added another 19 turtles.

Loggerhead turtles that we tracked migrating from Crete to 3 areas of the Eastern Mediterranean Sea differed in size and reproductive output. These fitness comparisons for turtles of different foraging regions were similar to those reported in previous

mollusks, and crustaceans, though at abundances of only 1700 ind. ha ${ }^{-1}$ in the $<50 \mathrm{~m}$ stations, 350 ind. $\mathrm{ha}^{-1}$ in the 50 to $100 \mathrm{~m}$ stations, and 200 ind. ha ${ }^{-1}$ in the stations between 100 and $200 \mathrm{~m}$. From the data of Dimitriou et al. (2012), we counted a total of 75 species of prey items for loggerheads in Crete and the Aegean Sea. In Crete, the abundance of these 75 species was 6245 ind. $\mathrm{ha}^{-1}$ in the $<50 \mathrm{~m}$ stations, 1832 ind. ha ${ }^{-1}$ in the 50 to $100 \mathrm{~m}$ stations, and 631 ind. ha ${ }^{-1}$ in the 100 to $200 \mathrm{~m}$ stations (Dimitriou et al. 2012). In the Aegean Sea, sampling stations did not reach beyond $50 \mathrm{~m}$, and the abundance was 10110 ind. $\mathrm{ha}^{-1}$ within the $<50 \mathrm{~m}$ depth range (data from Dimitriou et al. 2012).

\section{DISCUSSION}

Loggerhead nesting in the Mediterranean Sea occurs primarily in Greece (Margaritoulis et al. 2003). Major foraging locations are in the Gulf of Gabès region of Tunisia and in the Adriatic and Aegean Seas (Margaritoulis \& Rees 2011), with loggerheads tracked in this region showing a very high level of foraging site fidelity (Broderick et al. 2007, Casale et al. 2013). Despite long-term protection of many log- studies (Fig. 3). However, the causes for these differences are not known. We believe that they are due to differences in benthic productivity in these regions. The Eastern Mediterranean basin is among the most oligotrophic areas in the world (Lampadariou \& Tselepides 2006), and Greek loggerheads are much smaller than their Atlantic and Pacific counterparts (Margaritoulis et al. 2003). However, net primary productivity is unusually high on the eastern coasts of Tunisia, specifically in the Gulf of Gabès region (Drira et al. 2008). The high level of primary productivity is not reflected in the benthic prey abundance. Instead, it is due to high levels of anthropogenic inputs from major coastal cities like Gabès and Sfax that have led to a constant state of eutrophication in these waters (Drira et al. 2008) that does not translate into increased secondary productivity.

The Gulf of Gabès region is heavily exploited by a variety of fisheries, with an absolute annual catch of $43000 \mathrm{t}$, compared to $19600 \mathrm{t}$ in the Aegean Sea (Hattab et al. 2013). When compared to the northern Aegean fisheries, the fishing strategies are similar in both ecosystems; however, the efficiency of the fishery in the Gabès region is lower than that in the Aegean Sea and also lower than that in the Adriatic Sea (Tsagarakis et al. 2010, Hattab et al. 2013). This 


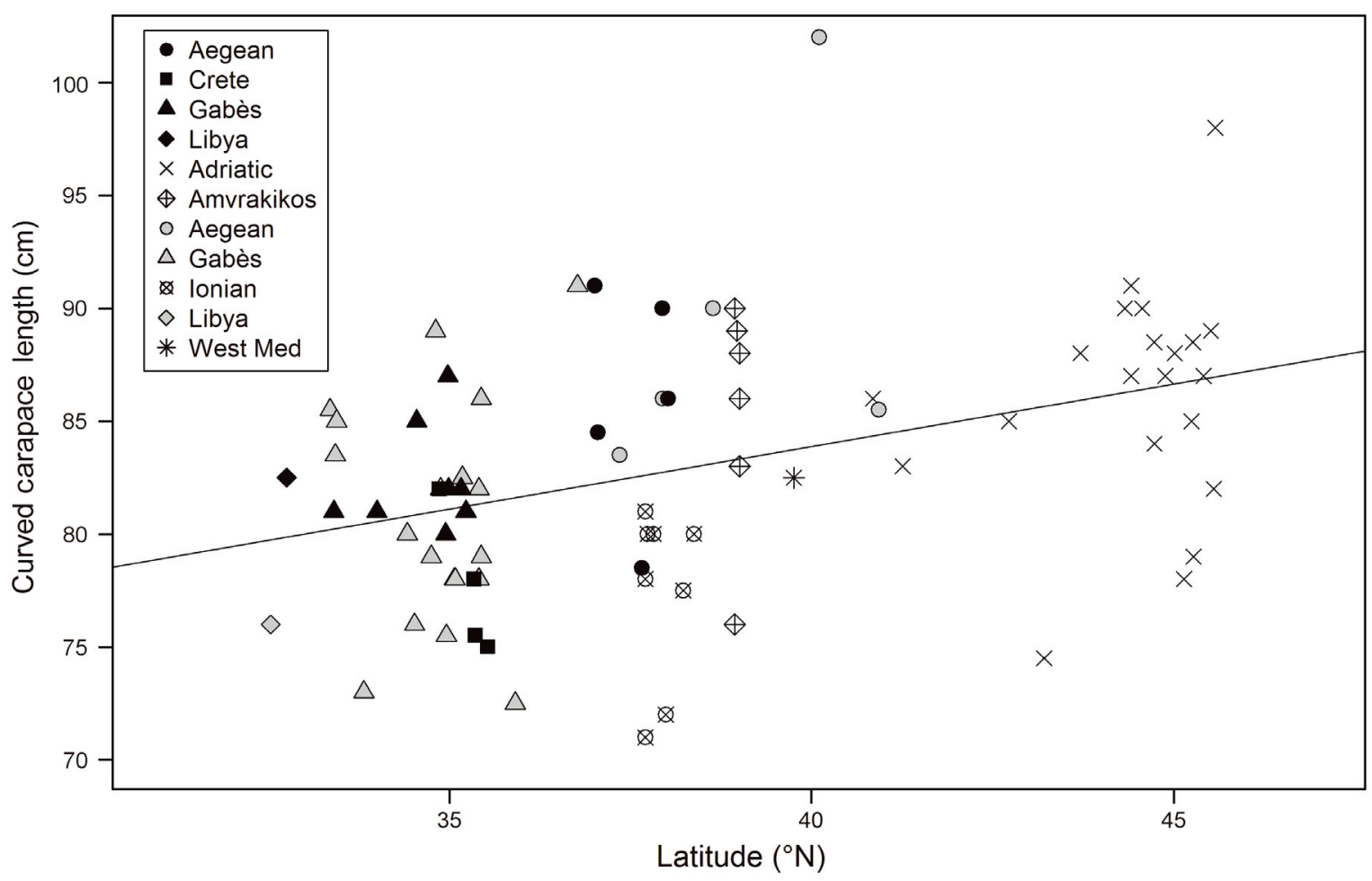

Fig. 3. Comparison of curved carapace length of loggerhead turtles Caretta caretta with latitude of foraging area. Solid black symbols represent data from this study; the remaining symbols represent data from Schofield et al. (2013). The solid line represents the trend line for the combination of data from both studies, $\mathrm{R}^{2}=0.1653, y=0.5527 x+61.765$

low efficiency, combined with fishers exceeding the optimal fishing effort and the maximum sustainable yield, has led to a $25 \%$ decline in fish production since the 1980s in the Gabès region (Hattab et al. 2013). These substantial fisheries impacts to the ecosystem of the Tunisian shelf, combined with the high levels of eutrophication, may play important roles in reducing the overall prey species available for loggerheads in the region (Turki et al. 2006, Ben Brahim et al. 2010, Hattab et al. 2013). Although the sampling techniques for the benthic species abundances were not directly comparable (Jørgensen et al. 2011), i.e. trawls in the Gabès region vs. grabs in the Aegean and Cretan regions, the results, when combined with overall ecosystems assessments, provide insight into the variations between the 3 regions in terms of prey abundances.

Foraging regions have been linked to body sizes in turtle populations (Saba et al. 2008a,b), and typically, loggerheads that forage farther offshore, in lownutrient pelagic waters, tend to be smaller than their nearshore benthic foraging counterparts (Hawkes et al. 2006, Hatase et al. 2010, 2013, Reich et al. 2010, Eder et al. 2012). However, this does not seem to be the case at the foraging site within the Gulf of Gabès region. When comparing the sizes of the 8 turtles that traveled to this region, the 4 that foraged $>40 \mathrm{~km}$ from shore $(C C L$ mean \pm SD: $83.9 \pm 2.4 \mathrm{~cm}$; SCL: 79.9 $\pm 2.2 \mathrm{~cm}$ ) were longer on average than the turtles that resided close to shore (CCL: $80.8 \pm 0.500 \mathrm{~cm}$; SCL: $77.3 \pm 1.2 \mathrm{~cm}$ ). In addition, mean clutch sizes for those loggerheads foraging offshore of the Gulf of Gabès region $\left(\mathrm{n}_{\text {clutches }}=11\right.$, mean $\pm \mathrm{SD}=101 \pm 19.0$ eggs) were larger than those remaining nearshore $\left(\mathrm{n}_{\text {clutches }}=6\right.$, mean $\pm \mathrm{SD}=92.0 \pm 15.2$ eggs $)$. Although there were relatively higher levels of chlorophyll $a$ nearshore $\left(130 \mathrm{ng} \mathrm{l}^{-1}\right)$ than farther offshore $\left(30 \mathrm{ng} \mathrm{l}^{-1}\right)$ (Drira et al. 2008), the higher level of harmful algal blooms along the coastline (Bel Hassen et al. 2008) reduced the transfer of energy up the food chain to the benthic macroinvertebrates that provided food for loggerheads.

The Gulf of Gabès region is characterized as having an extended continental shelf area, and as such the offshore turtles are still able to forage in the benthic environment, unlike the smaller oceanic foraging loggerheads described in previous studies, as these are pelagic foragers (Hawkes et al. 2006, Hatase et al. 2010, 2013, Reich et al. 2010, Eder et al. 2012). Turtles residing offshore of Tunisia primarily 
foraged in waters with a maximum depth of $50 \mathrm{~m}$ $(\sim 80 \%$ of dives were within a depth of $50 \mathrm{~m}$, and $\sim 90 \%$ were within $75 \mathrm{~m}$ ) and stayed within a much smaller horizontal range than the oceanic foragers described by Hawkes et al. (2006). In addition, the turtles foraged much closer to the Strait of Sicily, where the waters were more directly affected by currents traveling west to east. This may be a contributing factor towards maintaining more mixed and less eutrophic environmental conditions.

Trawl studies indicate that the waters of the Gulf of Gabès region with a maximum depth of $60 \mathrm{~m}$ have a much higher macrobenthic species abundance than the deeper waters (<60 m: 1700 ind. $\mathrm{ha}^{-1}$; > $60 \mathrm{~m}: 350$ ind. ha ${ }^{-1}$ ), and this corresponds to the presence of Posidonia oceanica beds (El Lakhrach et al. 2012). Casale et al. (2008) commonly found sea grass within the gut and feces of benthic foraging loggerheads from Tunisia. However, due to the influx of anthropogenic waste, these sea grass beds are quickly degrading, with a decline in shoot density and an increased presence of large areas of dead meadows (Ben Brahim et al. 2010, El Lakhrach et al. 2012). Furthermore, nearshore benthic assessments north and south of Gabès City indicate that species abundances tend to be higher as the distance from direct anthropogenic inputs increases (Tlig-Zouari et al. 2009, Rabaoui et al. 2010, Derbali et al. 2012). As a result, the inshore prey quality may be much lower than offshore due to the increased levels of industrial and municipal runoff.

The turtles that remained near Crete were generally smaller than the Aegean group, and this probably was also due to a general lack of prey in the area. The waters of Crete are more oligotrophic than the Aegean, and have lower benthic macrofaunal density and biomass than other ecosystems at comparable depths throughout the world, including environments with sea turtle foraging (Karakassis \& Eleftheriou 1997). Specifically, the Cretan benthos (from 0 to $50 \mathrm{~m}$ depth) contains only $\sim 62 \%$ of the amount of prey items per $\mathrm{m}^{2}$ as compared to the Aegean Sea (Dimitriou et al. 2012). Also, the benthic environment around Crete is more limited, as the continental shelf is particularly narrow, extending at most only $13 \mathrm{~km}$ from shore (Karakassis \& Eleftheriou 1997), while the shelf extends over $200 \mathrm{~km}$ from the shore in the Gulf of Gabès region and over $300 \mathrm{~km}$ in the Adriatic. This was reflected in the dive data, as the Cretan turtles spent more dive time below $50 \mathrm{~m}$ than the long-distance migrants (Crete: 15.5\% of dives and $20.9 \%$ of dive time deeper than $50 \mathrm{~m}$; Africa: $6.5 \%$ of dives and $5.8 \%$ of dive time; Aegean:
$3.9 \%$ of dives and $6.2 \%$ of dive time; Patel 2013). In addition, the macrobenthic fauna abundance around Crete drops by approximately $75 \%$ and $85 \%$, respectively, as the depth increases from $<50 \mathrm{~m}$ to $100 \mathrm{~m}$ and to $200 \mathrm{~m}$ (Tselepides et al. 2000, Dimitriou et al. 2012). The turtles tracked in all regions never dove beyond $200 \mathrm{~m}$ in depth (Patel 2013). Furthermore, the Cretan turtles were significantly less active during foraging behavior (fewer dives per sample period) than both the Tunisian and Aegean turtles (Patel 2013), another potential indication of a lack of food availability, given that a reduction in foraging activity occurs in marine animals during times of reduced food availability (Sogard \& Olla 1996, Wikelski \& Thom 2000).

It is important to understand why the Aegean Sea is home to the most fecund turtles. Although this sea is considered oligotrophic, there is a constant input of cold, low-salinity and high-nutrient water from the Black Sea that displaces the warm, hypersaline waters traveling north along the Turkish coast (Lampadariou \& Tselepides 2006). With this increased level of mixing, this region supports some of the highest species richness of fish and invertebrates for the entire Eastern Mediterranean (Coll et al. 2010). Furthermore, the Aegean Sea is characterized as having a much higher macrobenthic species abundance (specifically ind. ha ${ }^{-1}$ of mollusks, crustaceans, and echinoderms) than Cretan waters and the Gulf of Gabès region (Abelló et al. 2002, Belcari et al. 2002, Karakassis \& Eleftheriou 1997, Dimitriou et al. 2012, El Lakhrach et al. 2012).

Overall, it appears that the quality and abundance of prey in the northern Mediterranean waters, the Aegean and the Adriatic Seas, play a critical role in maintaining larger and more fecund turtle individuals. Zakynthos Island, in western Greece, hosts the largest nesting population in the region, with turtles migrating from the Gulf of Gabès region as well as the Adriatic and Aegean Seas (Margaritoulis 2005, Zbinden et al. 2008, Schofield et al. 2013, Luschi \& Casale 2014). Considering the increasingly eutrophic conditions of the Gulf of Gabès region, it may be expected that overall clutch sizes at Zakynthos and Rethymno will decrease.

As of 2002, there was no indication of decreasing average clutch size for Zakynthos Island (Margaritoulis 2005), even though satellite telemetry and flipper tag data suggest that the Gulf of Gabès region is home to 28 to $44.4 \%$ of the females nesting in western Greece (Margaritoulis et al. 2003, Zbinden et al. 2011, Schofield et al. 2013). However, in the period between 2003 and 2009, clutch sizes have begun to 
decline, with the average dropping to 106.7 eggs clutch $^{-1}$ from a minimum mean of 111.4 eggs clutch ${ }^{-1}$ reported between 1982 and 2002 (Margaritoulis et al. 2011). Based on telemetry and flipper tag data, it appears that 28.6 to $47.4 \%$ of loggerheads nesting in Rethymno forage in the southern waters, and the overall annual number of nests continues to decline (Margaritoulis et al. 2009). In the Gulf of Gabès region, the influx of industrial runoff began in the 1970s and the first occurrence of harmful algal blooms occurred in 1989 (Turki et al. 2006). Casale et al. (2011) identified that loggerheads nesting in the Mediterranean take between 23.5 and $29.3 \mathrm{yr}$ to reach sexual maturity. As a result, reproductively active female turtles currently nesting may be some of the first to be showing signs of decreasing reproductive fitness, as expressed in reduced total output, especially given the fact that sea turtles have been shown to be affected by limited food availability (Wallace et al. 2006, Saba et al. 2007, Chaloupka et al. 2008).

Several steps should be taken to ensure the survival of the loggerhead nesting populations of Greece. For example, the reduction of anthropogenic inputs (industrial runoff, sewage, and fertilizer) in the Gulf of Gabès region could help improve the quality of the benthic environment in an area where close to $40 \%$ of nesting females from Greece forage. As global temperatures climb, the impacts of eutrophication are expected to increase, with harmful algal blooms occurring at higher rates (Edwards et al. 2006). Furthermore, an increase in light attenuation caused by algal blooms will severely reduce the presence of the sea grass beds critical for the survival of benthic invertebrates (Lloret et al. 2008). Another conservation concern is the improved protection of the northern foraging turtles, as they are important in helping sustain higher reproductive outputs. Sea turtles foraging in the north, regardless of size, were able to produce larger clutch sizes on average. As a result, this population could help balance the reduced reproductive output of the non-migrants and the females foraging in the south.

Further research is required to help improve our understanding of this dichotomy in fitness. A more complete assessment of fitness parameters (remigration intervals and nests per season) would be useful in determining whether the turtles with the various migratory strategies are in fact nesting at different frequencies depending on clutch size or migration distance. This increased understanding could be used to prioritize and focus conservation efforts. For example, if the Cretan turtles, with their lack of migration, are in fact nesting yearly, their lifetime reproductive output may match that of the turtles foraging in the north. Furthermore, the Aegean turtles are on average $\sim 1000 \mathrm{~km}$ closer to the nesting beach than the long-distance migrants to Africa, thus they may also return to nest more frequently. This in turn could focus the reason for the reduction in nesting output in Rethymno to the reduced foraging success of the turtles residing specifically along the North African coast. As has been demonstrated previously, this African region is critical for juveniles (Casale et al. 2008), post-nesting females (Broderick et al. 2007, Zbinden et al. 2008, 2011, Patel 2013), and postreproductive males (Casale et al. 2013, Schofield et al. 2013, Patel et al. in press) during foraging and overwintering alike.

Acknowledgements. This project was funded by The Betz Chair of Environmental Science at Drexel University and by The Leatherback Trust, Monterrey, California. Assistance in the collection of these data was provided by the many generous leaders and volunteers of ARCHELON, the Sea Turtle Protection Society of Greece. Specifically, those at the ARCHELON site in Rethymno during the 2010-2011 seasons provided generous assistance in ensuring proper data collection. Michael P. O'Connor, Harold W. Avery, Nathan J. Robinson, and the anonymous reviewers provided critical feedback in improving this manuscript.

\section{LITERATURE CITED}

Abelló P, Abella A, Adamidou A, Jukic-Peladic S, Maiorano P, Spedicato MT (2002) Geographical patterns in abundance and population structure Nephrops norvegicus and Parapenaeus longirostris (Crustacea: Decapoda) along the European Mediterranean coasts. Sci Mar 66: 125-141

Bailey H, Fossette S, Bograd SJ, Shillinger GL and others (2012) Movement patterns for a critically endangered species, the leatherback turtle (Dermochelys coriacea), linked to foraging success and population status. PLoS ONE 7:e36401

Bel Hassen M, Drira Z, Hamza A, Ayadu H, Akrout F, Issaoui $\mathrm{H}$ (2008) Summer phytoplankton pigments and community composition related to water mass properties in the Gulf of Gabès. Estuar Coast Shelf Sci 77:645-656

Belcari P, Cuccu D, Gonzalez M, Srairi A, Vidoris P (2002) Distribution and abundance of Octopus vulgaris Cuvier, 1797 (Cephalopoda: Octopoda) in the Mediterranean Sea. Sci Mar 66:157-166

> Ben Brahim M, Hamza A, Hannachi I, Rebai A, Jarboui O, Bouain A, Aleya L (2010) Variability in the structure of the epiphytic assemblage of Posidonia oceania in relation to human interferences in the Gulf of Gabès, Tunisia. Mar Environ Res 70:411-421

- Blanco GS, Morreale SJ, Bailey H, Seminoff JA, Paladino FV, Spotila, JR (2012a) Post-nesting movements and feeding grounds of a resident East Pacific green turtle Chelonia mydas population from Costa Rica. Endang Species Res 18:233-245 
Blanco GS, Morreale SJ, Vélez E, Piedra R, Montes WM, Paladino FV, Spotila JR (2012b) Reproductive output and ultrasonography of an endangered population of East Pacific green turtles. J Wildl Manag 76:841-846

Boyle WA, Conway CJ (2007) Why migrate? A test of the evolutionary precursor hypothesis. Am Nat 169:344-359

Broderick AC, Coyne MS, Fuller WJ, Glen F, Godley BJ (2007) Fidelity and over-wintering of sea turtles. Proc R Soc Lond B Biol Sci 274:1533-1539

Cardona L, Clusa M, Eder E, Demetropoulos A and others (2014) Distribution patterns and foraging ground productivity determine clutch size in Mediterranean loggerhead turtles. Mar Ecol Prog Ser 497:229-241

- Carreras C, Pascual M, Cardona L, Aguilar A and others (2007) The genetic structure of the loggerhead sea turtle (Caretta caretta) in the Mediterranean as revealed by nuclear and mitochondrial DNA and its conservation implications. Conserv Genet 8:761-775

Casale P, Abbate G, Freggi D, Conte N, Oliverio M, Argano R (2008) Foraging ecology of loggerhead sea turtles Caretta caretta in the central Mediterranean Sea: evidence for a relaxed life history model. Mar Ecol Prog Ser 372:265-276

> Casale P, Mazaris AD, Freggi D (2011) Estimation of age at maturity of loggerhead sea turtles Caretta caretta in the Mediterranean using length-frequency data. Endang Species Res 13:123-129

Casale P, Freggi D, Cinà A, Rocco M (2013) Spatio-temporal distribution and migration of adult male loggerhead sea turtles (Caretta caretta) in the Mediterranean Sea: further evidence of the importance of neritic habitats off North Africa. Mar Biol 160:703-718

Chaloupka M, Kamezaki N, Limpus C (2008) Is climate change affecting the population dynamics of the endangered Pacific loggerhead sea turtle? J Exp Mar Biol Ecol 356:136-143

Coll M, Piroddi C, Steenbeek J, Kashner K and others (2010) The biodiversity of the Mediterranean Sea: estimates, patterns and threats. PLoS ONE 5:e11842

> Corkeron PJ, Connor RC (1999) Why do baleen whales migrate? Mar Mamm Sci 15:1228-1245

Derbali A, Elhasni K, Jarboui O, Ghorbel M (2012) Distribution, abundance and biological parameters of Cerastoderma glaucum (Mollusca: Bivalvia) along the Gabès coasts (Tunisia, Central Mediterranean). Acta Adriat 53: 364-374

> Dimitriou PD, Apostolaki ET, Papageorgiou N, Reizopoulou S, Simboura N, Arvanitidis C, Karakassis I (2012) Metaanalysis of a large data set with Water Framework Directive indicators and calibration of a Benthic Quality Index at the family level. Ecol Indic 20:101-107

> Drira Z, Hamza A, Bel Hassen M, Ayadi H, Bouain A, Aleya L (2008) Dynamics of dinoflagellates and environmental factors during the summer in the Gulf of Gabès (Tunisia, Eastern Mediterranean Sea). Sci Mar 72:59-71

Eder E, Ceballos A, Martins S, Pérez-Garcia H, Marin I, Marco A, Cardona L (2012) Foraging dichotomy in loggerhead sea turtles Caretta caretta off northwestern Africa. Mar Ecol Prog Ser 470:113-122

Edwards M, Johns DG, Leterme SC, Svendsen E, Richardson AJ (2006) Regional climate change and harmful algal blooms in the northeast Atlantic. Limnol Oceanogr 51: 820-829

El Lakhrach H, Hattour A, Jarboui O, Elhasni K, RamosEspla AA (2012) Spatial distribution and abundance of megabenthic fauna community in Gabès gulf (Tunisia, eastern Mediterranean Sea). Mediterr Mar Sci 13:12-29
Godley BJ, Smoth SM, Clark PF, Taylor JD (1997) Molluscan and crustacean items in the diet of the loggerhead turtle, Caretta caretta (Linnaeus, 1758) [Testudines: Chelonidae] in the eastern Mediterranean. J Molluscan Stud 63: $474-476$

Hatase H, Omuto K, Tsukamoto K (2010) Oceanic residents, neritic migrants: a possible mechanism underlying foraging dichotomy in adult female loggerhead turtles (Caretta caretta). Mar Biol 157:1337-1342

Hatase H, Omuta K, Tsukamoto K (2013) A mechanism that maintains alternative life histories in a loggerhead sea turtle population. Ecology 94:2583-2594

> Hattab T, Lasram FBR, Albouy C, Romdhane MS and others (2013) An ecosystem model of an exploited southern Mediterranean shelf region (Gulf of Gabes, Tunisia) and a comparison with other Mediterranean Ecosystem model priorities. J Mar Syst 128:159-174

> Hawkes LA, Broderick AC, Coyne MS, Godfrey MH and others (2006) Phenotypically linked dichotomy in sea turtle foraging requires multiple conservation approaches. Curr Biol 16:990-995

> Jenouvrier S, Barbraud C, Cazelles B, Weimerskirch H (2005) Modelling population dynamics of seabirds: importance of the effects of climate fluctuations on breeding proportions. Oikos 108:511-522

Jones TT, Bostrom BL, Carey M, Imlach B and others (2011) Determining transmitter drag and best practice attachment procedures for sea turtle biotelemetry studies. NOAA Tech Memo NMFS-SWFSC-480

Jørgensen LL, Renaud PE, Cochrane SKJ (2011) Improving benthic monitoring by combining trawl and grab surveys. Mar Pollut Bull 62:1183-1190

Karakassis I, Eleftheriou A (1997) The continental shelf of Crete: structure of macrobenthic communities. Mar Ecol Prog Ser 160:185-196

> Lampadariou N, Tselepides A (2006) Spatial variability of meiofaunal communities at areas of contrasting depth and productivity in the Aegean Sea (NE Mediterranean). Prog Oceanogr 69:19-36

Lazar B, Gracan R, Katic J, Zavodnik D, Jaklin A, Tvrtkovic N (2011) Loggerhead sea turtles (Caretta caretta) as bioturbators in neritic habitats: an insight through the analysis of benthic molluscs in the diet. Mar Ecol 32: 65-74

> Lescroël A, Ballard G, Toniolo V, Barton KJ, Wilson PR, Ainley DG (2010) Working less to gain more: when breeding quality relates to foraging efficiency. Ecology 91: 2044-2055

> Limpus CJ, Nicholls N (1988) The Southern Oscillation regulates the annual numbers of green turtles (Chelonia mydas) breeding around northern Australia. Wildl Res 15:157-161

Limpus CJ, Miller JD, Paramenter CJ, Reimer D, McLachlan N, Webb R (1992) Migration of green (Chelonia mydas) and loggerhead (Caretta caretta) turtles to and from eastern Australian rookeries. Wildl Res 19:347-357

Lloret J, Marin A, Marin-Guirao L (2008) Is coastal lagoon eutrophication to be aggravated by global climate change? Estuar Coast Shelf Sci 78:403-412

Logan P, Morreale SJ (1994) Hydrodynamic drag characteristics of juvenile L. kempii, C. mydas and C. caretta. In: Schroeder B, Witherington B (eds) Proceedings of the 13th Annual Symposium on Sea Turtle Biology and Conservation. Jekyll Island, Georgia. NMFS-SEFSC-341, p 205-208

Lohmann KJ, Witherington BE, Lohmann CMF, Salmon M (1997) Orientation, navigation, and natal beach homing 
in sea turtles. In: Lutz PL, Musick JA (eds) The biology of sea turtles. CRC Press, Boca Raton, FL, p 137-164

Luschi P, Casale P (2014) Movement patterns of marine turtles in the Mediterranean Sea: a review. Ital J Zool 81: 478-495

Margaritoulis D (2005) Nesting activity and reproductive output of loggerhead sea turtles, Caretta caretta, over 19 seasons (1984-2002) at Laganas Bay, Zakynthos, Greece: the largest rookery in the Mediterranean. Chelonian Conserv Biol 4:916-929

Margaritoulis D, Rees A (2011) Loggerhead turtles nesting at Rethymno, Greece, prefer the Aegean Sea as their main foraging area. Mar Turtle Newsl 131:12-14

Margaritoulis D, Argano R, Baran I, Bentivegna F and others (2003) Loggerhead turtles in the Mediterranean Sea: present knowledge and conservation perspectives. In: Bolton $\mathrm{AB}$, Witherington $\mathrm{BE}$ (eds) Loggerhead sea turtles. Smithsonian Books, Washington, DC, p 175-198

Margaritoulis D, Panagopoulou A, Rees A (2009) Loggerhead nesting in Rethymno, Island of Crete, Greece: fifteen-year nesting data (1990-2004) indicate a declining population. In: Demetropoulos A, Turkozan O (eds) Proc 2nd Mediterr Conf Mar Turtles, Kemer, p 116-119

Margaritoulis D, Rees AF, Dean CJ, Riggall T (2011) Reproductive data of loggerhead turtles in Laganas Bay, Zakynthos Island, Greece, 2003-2009. Mar Turtle Newsl 131:2-6

Morreale SJ, Standora EA, Spotila JR, Paladino FV (1996) Migration corridor for sea turtles. Nature 384:319-320

Morreale SJ, Plotkin PT, Shaver DJ, Kalb HJ (2007) Adult migration and habitat utilization: ridley turtles in their element. In: Plotkin PT (ed) Biology and conservation of the ridley sea turtle. The John Hopkins University Press, Baltimore, MD, p 213-229

Musick JA, Limpus CJ (1997) Adult migrations and habitat use. In: Lutz PL, Musick JA (eds) The biology of sea turtles. CRC Press, Boca Raton, FL, p 137-164

Patel SH (2013) Movements, behaviors and threats to loggerhead turtles (Caretta caretta) in the Mediterranean Sea. PhD dissertation, Drexel University, Philadelphia, PA

Patel SH, Panagopoulou A, Morreale SJ, Paladino FV, Margaritoulis D, Spotila JR (in press) Post-reproductive migration of an adult male loggerhead from Crete revealed by satellite telemetry. In: Proceedings from the 32nd Annual International Sea Turtle Symposium

Plotkin PT (2003) Adult migrations and habitat use. In: Lutz PL, Musick JA, Wyneken J (eds) The biology of sea turtles, Vol 2. CRC Press, Boca Raton, FL, p 225-241

R Core Team (2015) R: a language and environment for statistical computing. R Foundation for Statistical Computing, Vienna. www.R-project.org/

Rabaoui L, Tlin-Zouari S, Katsanevakis S, Ben Hassine OK (2010) Modelling population density of Pinna nobilis (Bivalvia) on the eastern and southeastern coast of Tunisia. J Molluscan Stud 76:340-374

Reich KJ, Bjorndal KA, Frick MG, Witherington BE, Johnson C, Bolton AB (2010) Polymodal foraging and adult female loggerheads (Caretta caretta). Mar Biol 157:113-121

Rostal DC, Paladino FV, Patterson RM, Spotila JR (1996) Reproductive physiology of nesting leatherback turtles (Dermochelys coriacea) at Las Baulas National Park, Costa Rica. Chelonian Conserv Biol 2:230-236
Saba VS, Santidrián-Tomillo P, Reina RD, Spotila JR, Musick JA, Evans DA, Paladino FV (2007) The effect of the El Niño Southern Oscillation on the reproductive frequency of eastern Pacific leatherback turtles. J Appl Ecol 44: 395-404

Saba VS, Shillinger GL, Swithenbank AM, Block BA, Spotila JR, Musick JA, Paladino FV (2008a) An oceanographic context for the foraging ecology of eastern Pacific leatherback turtles, consequences of ENSO. Deep-Sea Res I 55:646-660

Saba VS, Spotila JR, Chavez FP, Musick JA (2008b) Bottomup and climatic forcing on the worldwide population of leatherback turtles. Ecology 89:1414-1427

Schofield G, Dimadi A, Fossette S, Katselidis KA and others (2013) Satellite tracking large numbers of individuals to infer population dispersal and core areas for the protection of an endangered species. Divers Distrib 19:834-844

Sogard SM, Olla BL (1996) Food deprivation affects vertical distribution and activity of a marine fish in a thermal gradient: potential energy-conserving mechanisms. Mar Ecol Prog Ser 133:43-55

> Solow AR, Bjorndal KA, Bolten AB (2002) Annual variation in nesting numbers of marine turtles: the effect of sea surface temperature on re-migration intervals. Ecol Lett 5:742-746

Tiwari M, Bjorndal KA (2000) Variation in morphology and reproduction in loggerheads, Caretta caretta, nesting in the United States, Brazil, and Greece. Herpetologica 56: 343-356

Tlig-Zouari S, Rabaoui L, Irathni I, Ben Hassine OK (2009) Distribution, habitat and population densities of the invasive species Pinctada radiata (Mollusca: Bivalvia) along the Northern and Eastern coasts of Tunisia. Cah Biol Mar 50:131-142

Tsagarakis K, Coll M, Giannoulaki M, Somarakis S, Papaconstantinou C, Machias A (2010) Food-web traits of the North Aegean Sea ecosystem (Eastern Mediterranean) and comparison with other Mediterranean ecosystems. Estuar Coast Shelf Sci 88:233-248

Tselepides A, Papadopoulou KN, Podaras D, Plaiti W, Koutsoubas D (2000) Macrobenthic community structure over the continental margin of Crete (South Aegean Sea, NE Mediterranean). Prog Oceanogr 46:401-428

Turki S, Harzallah A, Sammari C (2006) Occurrence of harmful dinoflagellates in two different Tunisian ecosystems: the lake of Bizerte and the gulf of Gabès. Cah Biol Mar 47:253-259

Wallace BP, Kilham SS, Paladino FV, Spotila JR (2006) Energy budget calculations indicate resource limitation in Eastern Pacific leatherback turtles. Mar Ecol Prog Ser 318:263-270

Wikelski M, Thom C (2000) Marine iguanas shrink to survive El Niño. Nature 403:37-38

- Zbinden JA, Aebischer A, Margaritoulis D, Arlettaz R (2008) Important areas at sea for adult loggerhead sea turtles in the Mediterranean Sea: satellite tracking corroborates findings from potentially biased sources. Mar Biol 153: 899-906

> Zbinden JA, Bearhop S, Bradshaw P, Gill B, Margaritoulis D, Newton J, Godley BJ (2011) Migratory dichotomy and associated phenotypic variation in marine turtles revealed by satellite tracking and stable isotope analysis. Mar Ecol Prog Ser 421:291-302

Submitted: March 10, 2015; Accepted: July 19, 2015

Proofs received from author(s): September 2, 2015 